Brit. Heart f., 1969, 31, 118.

\title{
Resting Hyperventilation in Adults with Atrial Septal Defect
}

\author{
J. RESSL, M. KUBIS, P. LUKL, J. VYKYDAL, AND J. WEINBERG \\ From the First Department of Medicine, Palacký University Medical School, Olomouc, Czechoslovakia
}

Pulmonary functions may be considerably influenced by changes in pulmonary haemodynamics in congenital heart disease. In analysing this problem we have found resting hyperventilation to be a common finding in these patients. There are few published studies on this relation and those that exist do not agree. In the present study the resting hyperventilation has been related to the pulmonary circulatory changes in a group of adults with atrial septal defect with particular regard being paid to the question whether there exists any correlation between the resting ventilation and pulmonary hypertension or the magnitude of the left-to-right shunt.

\section{SUBJECTS AND METHODS}

Studies have been made of 37 patients with atrial septal defect of the secondary type (26 women and 11 men), whose ages ranged from 15 to 65 years (average 29.8 years). All other congenital heart diseases have been excluded, with the exception of concomitant anomalous pulmonary venous drainage.

The diagnosis was confirmed by clinical, $x$-ray, and electrocardiographic examination, and in all patients by cardiac catheterization. This was performed in the usual way without any premedication in the fasting state. The pressure in all compartments of the right heart as well as the vascular pulmonary resistance was measured. The mean pulmonary arterial pressure was measured by electrical integration on Elema Minograph 42 apparatus. After reaching steady state, cardiac output was calculated by Fick principle. Expired gas was collected in a Douglas bag and analysed for $\mathrm{O}_{2}$ and $\mathrm{CO}_{2}$ by a Zeiss interpherometer. Blood oxygen analysis was done in an Oximeter Elema (checked by a Van Slyke apparatus). For arterial blood a Cournand needle was placed in the femoral artery. The left-to-right shunt was expressed in absolute values and in percentage of total pulmonary blood flow.

The ventilatory studies were made with a 13-litre

Received June 27, 1968. closed circuit apparatus Expirator Prema filled with oxygen in a steady state but not in basal conditions, with the patient seated, at least 2 hours after the last meal. Resting minute ventilation was expressed in $1 . / \mathrm{min}$. and in $1 . / \mathrm{min}$. per square meter of body surface, and tidal volume in $\mathrm{ml}$. The observed values were corrected to BTPS (body temperature, ambient pressure, saturated water vapour). Breathing frequency per minute was recorded during the spirometric examination. This examination was made the day before cardiac catheterization. The statistical relation was calculated by means of Student's t-test and the correlation coefficient.

The patients were divided into two groups according to their pulmonary artery pressure; $20 \mathrm{~mm}$. $\mathrm{Hg}$ of mean pulmonary arterial pressure was considered to be upper normal limit. In the first group with normal pulmonary pressure were 26 patients (average age 27 years); in the second group 11 patients with pulmonary hypertension ranging from 23 to $96 \mathrm{~mm}$. $\mathrm{Hg}$ of mean pulmonary arterial pressure (average age 39 years). In only one patient (Case 35) was the pulmonary hypertension of hyperkinetic type; in all others the arteriolar pulmonary resistance was raised.

\section{RESULTS}

The ventilatory and haemodynamic findings are shown in Table I. The average minute ventilation per square meter of body surface $\left(M \dot{\mathrm{V}} / \mathrm{m} .{ }^{2}\right)$ in all patients was $7.0 \pm 1.61 . / \mathrm{min} . / \mathrm{m}^{2}{ }^{2}$ which is clearly higher than the normal value of $4 \cdot 8 \pm 1 \cdot 1 \mathrm{l} / \mathrm{min} . / \mathrm{m} .^{2}$ in our laboratory by the same procedure. The results in the two groups were as follows:

Group 1 (no pulmonary hypertension): $6 \cdot 4 \pm 1 \cdot 4$ $1 . / \mathrm{min} . / \mathrm{m}^{2}$

Group 2 (pulmonary hypertension): $8 \cdot 5 \pm 1 \cdot 3$ $1 . / \mathrm{min} . / \mathrm{m} .^{2}$

The difference between the two groups is statistically highly significant $(t=4.499 ; p<0.001)$.

When the minute ventilation was expressed in 118 
Resting Hyperventilation in Adults with Atrial Septal Defect

TABLE I

VENTILATORY AND HAEMODYNAMIC DATA

\begin{tabular}{|c|c|c|c|c|c|c|c|c|c|c|c|c|}
\hline \multirow{2}{*}{\multicolumn{3}{|c|}{$\begin{array}{l}\text { Case No., sex, } \\
\text { and age }\end{array}$}} & \multicolumn{2}{|c|}{ Minute ventilation } & \multirow{2}{*}{$\begin{array}{l}\text { Tidal } \\
\text { vol. } \\
\text { (ml.) }\end{array}$} & \multirow{2}{*}{$\begin{array}{c}\text { Breathing } \\
\text { frequency/ } \\
\text { min. }\end{array}$} & \multirow{2}{*}{$\begin{array}{c}\text { Mean } \\
\text { pulm. art. } \\
\text { pressure } \\
\text { (mm. Hg) }\end{array}$} & \multicolumn{3}{|c|}{ Left-to-right shunt } & \multirow{2}{*}{$\begin{array}{c}\text { Total } \\
\text { pulm. } \\
\text { blood } \\
\text { flow } \\
\text { (1./min.) }\end{array}$} & \multirow{2}{*}{$\begin{array}{c}\text { Art. } \mathrm{O}_{2} \\
\text { satn } \\
(\%)\end{array}$} \\
\hline & & & $1 . / \mathrm{min}$. & $\underset{\mathrm{m} .{ }^{2}}{1 . / \mathrm{min}}$ & & & & $\begin{array}{c}\% \text { total } \\
\text { pulm. } \\
\text { blood flow }\end{array}$ & $1 . / \mathrm{min}$. & $\underset{\mathrm{m}^{2} .^{2} /}{1 . / \mathrm{min}}$ & & \\
\hline \multicolumn{13}{|c|}{ Group 1 (pulmonary hypertension absent) } \\
\hline $\begin{array}{r}1 \\
2 \\
3 \\
4 \\
5 \\
6 \\
7 \\
8 \\
9 \\
10 \\
11 \\
12 \\
13 \\
14 \\
15 \\
16 \\
17 \\
18 \\
19 \\
20 \\
21 \\
22 \\
23 \\
24 \\
25 \\
26\end{array}$ & $\begin{array}{l}F \\
F \\
F \\
F \\
F \\
F \\
F \\
F \\
F \\
F \\
F \\
F \\
F \\
F \\
F \\
F \\
F \\
F \\
F \\
M \\
M \\
M \\
M \\
M \\
M \\
M \\
M\end{array}$ & $\begin{array}{l}26 \\
27 \\
44 \\
15 \\
15 \\
40 \\
33 \\
15 \\
15 \\
30 \\
35 \\
42 \\
18 \\
23 \\
40 \\
25 \\
18 \\
15 \\
18 \\
20 \\
18 \\
42 \\
18 \\
45 \\
16 \\
22\end{array}$ & $\begin{array}{r}9.2 \\
8.9 \\
9 \cdot 9 \\
7.5 \\
10.0 \\
12.1 \\
8.7 \\
9.7 \\
10.9 \\
10.4 \\
12.0 \\
10.0 \\
8.3 \\
10.6 \\
10.3 \\
11.2 \\
12.1 \\
8.3 \\
10.9 \\
6.7 \\
9.4 \\
13.0 \\
10.9 \\
12.2 \\
13.6 \\
9.0\end{array}$ & $\begin{array}{l}4 \cdot 9 \\
5 \cdot 9 \\
6 \cdot 2 \\
5 \cdot 2 \\
7 \cdot 6 \\
8 \cdot 1 \\
5 \cdot 1 \\
6 \cdot 4 \\
7 \cdot 4 \\
6 \cdot 2 \\
8 \cdot 7 \\
7 \cdot 6 \\
5 \cdot 9 \\
6 \cdot 2 \\
6 \cdot 3 \\
6 \cdot 4 \\
6 \cdot 5 \\
6 \cdot 2 \\
6 \cdot 8 \\
4 \cdot 1 \\
5 \cdot 5 \\
7 \cdot 0 \\
6 \cdot 7 \\
7 \cdot 3 \\
8 \cdot 6 \\
5 \cdot 1\end{array}$ & $\begin{array}{l}652 \\
556 \\
618 \\
500 \\
500 \\
526 \\
511 \\
538 \\
440 \\
547 \\
605 \\
500 \\
437 \\
481 \\
572 \\
589 \\
605 \\
436 \\
724 \\
515 \\
552 \\
722 \\
778 \\
677 \\
680 \\
428\end{array}$ & \begin{tabular}{|l|}
14 \\
16 \\
16 \\
15 \\
20 \\
23 \\
17 \\
18 \\
25 \\
19 \\
20 \\
20 \\
19 \\
22 \\
18 \\
19 \\
20 \\
19 \\
15 \\
13 \\
17 \\
18 \\
14 \\
18 \\
20 \\
21
\end{tabular} & $\begin{array}{l}11 \\
17 \\
15 \\
14 \\
10 \\
15 \\
19 \\
20 \\
13 \\
18 \\
14 \\
16 \\
17 \\
12 \\
17 \\
13 \\
15 \\
14 \\
14 \\
14 \\
16 \\
14 \\
17 \\
11 \\
15 \\
15\end{array}$ & \begin{tabular}{|l|}
59 \\
68 \\
47 \\
71 \\
58 \\
72 \\
40 \\
72 \\
61 \\
55 \\
65 \\
49 \\
75 \\
30 \\
29 \\
32 \\
28 \\
34 \\
15 \\
55 \\
64 \\
78 \\
79 \\
59 \\
36 \\
55
\end{tabular} & $\begin{array}{r}14 \cdot 29 \\
8 \cdot 80 \\
4 \cdot 41 \\
6 \cdot 55 \\
6.90 \\
15 \cdot 17 \\
2 \cdot 44 \\
14.55 \\
7 \cdot 06 \\
7 \cdot 08 \\
6 \cdot 62 \\
3.37 \\
10 \cdot 48 \\
2 \cdot 70 \\
2.37 \\
2 \cdot 05 \\
3.08 \\
2 \cdot 48 \\
1 \cdot 01 \\
6 \cdot 36 \\
13 \cdot 78 \\
10 \cdot 80 \\
14.21 \\
14 \cdot 29 \\
3.89 \\
4.93\end{array}$ & $\begin{array}{r}8 \cdot 46 \\
5.79 \\
2.75 \\
4.55 \\
5 \cdot 23 \\
10.01 \\
1.43 \\
10.89 \\
4 \cdot 70 \\
4 \cdot 21 \\
4.38 \\
2 \cdot 80 \\
7.43 \\
1.57 \\
1.47 \\
1.16 \\
1.65 \\
1.86 \\
0.63 \\
3.76 \\
7 \cdot 75 \\
5.79 \\
9.50 \\
8.50 \\
2.53 \\
2.77\end{array}$ & $\begin{array}{r}24 \cdot 40 \\
12.00 \\
9 \cdot 46 \\
9 \cdot 29 \\
11.90 \\
21.05 \\
6 \cdot 19 \\
20 \cdot 10 \\
11 \cdot 66 \\
13 \cdot 12 \\
10 \cdot 19 \\
6 \cdot 79 \\
13.98 \\
9 \cdot 20 \\
8 \cdot 34 \\
6 \cdot 35 \\
8 \cdot 74 \\
7 \cdot 21 \\
6.65 \\
11.50 \\
21 \cdot 65 \\
13.80 \\
18.00 \\
24.40 \\
10.65 \\
9.02\end{array}$ & 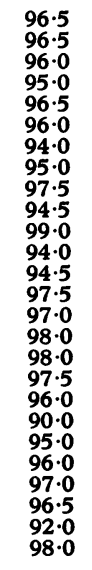 \\
\hline \multicolumn{13}{|c|}{ Group 2 (pulmonary hypertension) } \\
\hline $\begin{array}{l}27 \\
28 \\
29 \\
30 \\
31 \\
32 \\
33 \\
34 \\
35 \\
36 \\
37\end{array}$ & $\begin{array}{l}\mathrm{F} \\
\mathrm{F} \\
\mathrm{F} \\
\mathrm{F} \\
\mathrm{F} \\
\mathrm{F} \\
\mathrm{F} \\
\mathrm{F} \\
\mathrm{M} \\
\mathrm{M} \\
\mathrm{M}\end{array}$ & $\begin{array}{l}52 \\
65 \\
15 \\
49 \\
63 \\
31 \\
21 \\
15 \\
38 \\
52 \\
28\end{array}$ & $\begin{array}{r}14.9 \\
11.7 \\
7.9 \\
10.1 \\
9.0 \\
13.3 \\
13.1 \\
16.4 \\
16.1 \\
17.2 \\
14.2\end{array}$ & $\begin{array}{r}9 \cdot 7 \\
7 \cdot 4 \\
6 \cdot 0 \\
7 \cdot 2 \\
5.6 \\
9 \cdot 4 \\
9 \cdot 4 \\
11.9 \\
8.9 \\
8.9 \\
8.8\end{array}$ & $\begin{array}{l}876 \\
556 \\
493 \\
348 \\
530 \\
780 \\
569 \\
546 \\
766 \\
819 \\
710\end{array}$ & \begin{tabular}{|l|l|}
17 \\
21 \\
19 \\
29 \\
17 \\
17 \\
20 \\
30 \\
21 \\
23 \\
21
\end{tabular} & \begin{tabular}{|l}
25 \\
27 \\
30 \\
31 \\
33 \\
45 \\
91 \\
96 \\
23 \\
33 \\
66
\end{tabular} & \begin{tabular}{|l}
36 \\
63 \\
22 \\
24 \\
52 \\
57 \\
14 \\
30 \\
62 \\
69 \\
50
\end{tabular} & $\begin{array}{r}2.43 \\
5.98 \\
0.90 \\
1 \cdot 73 \\
4 \cdot 27 \\
3.20 \\
0.62 \\
1.62 \\
9 \cdot 70 \\
15.73 \\
6.88\end{array}$ & $\begin{array}{l}1.52 \\
3.63 \\
0.66 \\
1.23 \\
2.56 \\
2.25 \\
0.44 \\
1.17 \\
5.36 \\
7.79 \\
4.27\end{array}$ & $\begin{array}{r}6 \cdot 82 \\
9 \cdot 60 \\
4 \cdot 19 \\
7 \cdot 14 \\
8 \cdot 15 \\
5.65 \\
4 \cdot 46 \\
5 \cdot 62 \\
15.64 \\
22 \cdot 74 \\
13.79\end{array}$ & $\begin{array}{l}96.0 \\
86.0 \\
95.5 \\
90.5 \\
90.5 \\
96.0 \\
91.5 \\
88.0 \\
94.0 \\
95.0 \\
92.5\end{array}$ \\
\hline
\end{tabular}

For all patients the minute ventilation was $11 \cdot 0 \pm 2 \cdot 5$ 1./min.

Group 1 (no pulmonary hypertension): $10 \cdot 2 \pm 1 \cdot 7$ $1 . / \mathrm{min}$.

Group 2 (pulmonary hypertension): $13 \cdot 1 \pm 3 \cdot 7$ 1./min.

This difference is also statistically highly significant $(\mathrm{t}=3.991 ; \mathrm{p}<0.001)$.

The tidal volume of the average value of $596 \pm 124$ $\mathrm{ml}$. of the whole group was increased in pulmonary hypertension to $632 \pm 188 \mathrm{ml}$. in comparison with $579 \pm 105 \mathrm{ml}$. in patients with normal pulmonary artery pressure. The difference is statistically not significant $(t=1.293 ; p<0 \cdot 1)$. The average value of respiratory rate was $19 \pm 3 / \mathrm{min}$., in patients with normal pulmonary pressure $18 \pm 4$, and in pulmonary hypertension $21 \pm 5 / \mathrm{min}$. The difference is of lower statistical significance $(t=2.797 ; p<0.05)$.

From haemodynamic parameters the mean pulmonary arterial pressure, the left-to-right shunt as a percentage of total pulmonary blood flow and as an absolute value, the total pulmonary blood flow, and the arterial oxygen saturation were correlated with the minute ventilation, tidal volume, and respiratory rate. Table II shows that a highly significant correlation was found between the minute ventilation (both $\mathrm{MV} / \mathrm{m}^{2}$ and $M \dot{\mathrm{V}}$ ) and the mean pulmonary artery pressure and the respiratory rate $(p<0.01)$. There was no correlation of the other parameters.

\section{Discussion}

Resting hyperventilation in cardiac patients is a well-known phenomenon not yet completely understood. In some patients it may be the result of cardiac neurosis, as we have found in mitral stenosis, without any correlation with the haemodynamic changes (Ressl et al., 1961).

The increase in resting ventilation in congenital heart disease has been confirmed by many authors (Campbell, Hunt, and Poulton, 1923; Bing et al., 1948; Holling, 1952; Davison, Armitage, and 
TABLE II

CORRELATION COEFFICIENTS $r$

\begin{tabular}{|c|c|c|c|c|c|c|}
\hline & \multirow{2}{*}{$\begin{array}{l}\text { Pulm. art. } \\
\text { mean press. } \\
(\mathrm{mm} . \mathrm{Hg})\end{array}$} & \multicolumn{3}{|c|}{ Left-to-right shunt } & \multirow{2}{*}{$\begin{array}{l}\text { Total pulm. } \\
\text { blood flow } \\
(1 . / \mathrm{min} .)\end{array}$} & \multirow{2}{*}{$\underset{\substack{\text { Art. } \\
(\%)}}{\text { Oatn. }}$} \\
\hline & & $\begin{array}{l}\% \text { total pulm. } \\
\text { blood flow }\end{array}$ & 1. $/ \mathrm{min}$. & $1 . / \mathrm{min} . / \mathrm{m} .^{2}$ & & \\
\hline $\begin{array}{l}\text { Minute ventilation } \mathrm{m}^{2} \text { body surface } \\
\text { area }\end{array}$ & $0 \cdot 565$ & $-0 \cdot 159$ & -0.133 & -0.135 & -0.139 & -0.062 \\
\hline $\begin{array}{l}\text { Minute ventilation } \\
\text { Tidal volume } \\
\text { Breathing frequency }\end{array}$ & $\begin{array}{l}0.681 \\
0 \cdot 277 \\
0 \cdot 459\end{array}$ & $\begin{array}{r}-0.049 \\
0.153 \\
-0.225\end{array}$ & $\begin{array}{r}-0.081 \\
0.210 \\
-0.175\end{array}$ & $\begin{array}{r}-0.002 \\
0.120 \\
-0.183\end{array}$ & $\begin{array}{r}-0 \cdot 112 \\
0.215 \\
-0.150\end{array}$ & $\begin{array}{r}-0 \cdot 010 \\
0 \cdot 203 \\
-0 \cdot 115\end{array}$ \\
\hline
\end{tabular}

Arnott, 1953), but mainly in cyanotic patients. Surprisingly until now few data exist concerning the resting hyperventilation in acyanotic patients with left-to-right shunt.

Shephard (1955) found resting hyperventilation in congenital heart disease of cyanotic as well as of acyanotic type. In patients with right ventricular hypertension the resting respiratory rate was nearly normal and hyperventilation occurred in patients with increased pulmonary blood flow. Details of the cases as well as the pulmonary arterial pressure are not, unfortunately, given. This author found that the increase in resting ventilation in acyanotic patients was mainly in the respiratory rate, a fact confirmed by our results.

De Micheli et al. (1960) found a relation between the minute ventilation and left-to-right shunt in different types of congenital heart disease. In patients with pronounced pulmonary hypertension mild hyperventilation was present.

Gamalero (1957) studied the resting ventilation in children with congenital heart disease and found that hyperventilation was common. The ventilation equivalent for oxygen proved to be a useful indication in the evaluation of respiratory insufficiency. In a previous paper we studied a group of adults with atrial septal defect, and in them the oxygen ventilation equivalent at rest and during effort correlated well with pulmonary hypertension but not with the left-to-right shunt (Ressl and Kubis, 1968).

Krautwald et al. (1962) in a well-defined group of patients with left-to-right shunt without and with pulmonary hypertension found a good correlation between the resting hyperventilation and pulmonary artery pressure but no correlation with the magnitude of shunt. Such contradictory results from several authors might be the result of using different criteria for grouping patients (for example the right ventricular pressure is not significant for the presence of pulmonary hypertension). However, it was not possible to compare the results with the rest of the papers because of lack of detailed information in the case histories.
Changes in pulmonary haemodynamics in congenital heart disease with the left-to-right shunt may influence ventilation in several ways. One of them is the alteration in lung mechanics. It is well known that increased pulmonary blood flow and pulmonary hypertension in atrial septal defect are associated with a reduction in lung compliance (Davies and Gazetopoulos, 1967). But, as was shown by Woolf (1963), no relation between minute volume of respiration and compliance during exercise could be found. Other possible reasons for ventilatory difficulties are the anatomical changes in the lung. The morphology of lung vessels in patients with atrial septal defect and with normal pulmonary pressure is not much changed (Heath and Whitaker, 1957). Edwards (1957) has described fibrous intimal thickening in small pulmonary arteries and arterioles in patients with atrial septal defect and moderate pulmonary hypertension and more pronounced changes with severe pulmonary hypertension. The pulmonary abnormalities accompanying pulmonary hypertension in atrial septal defect might also affect pulmonary diffusing capacity. Auchincloss, Gilbert, and Eich (1959) found a significant increase in pulmonary diffusing capacity in patients with intracardiac septal defects and normal pulmonary pressure, normal or insignificantly raised values in moderate or marked degrees of pulmonary hypertension, and reduced values in marked pulmonary hypertension. The abovementioned results are consistent with the concept that pulmonary morphological changes in atrial septal defect with pulmonary hypertension may alter the lung mechanics and pulmonary diffusing capacity. Either of these conditions can cause a resting hyperventilation with close relation to the mean pulmonary arterial pressure in patients with atrial septal defect.

\section{SUMMARY}

In 37 adults with atrial septal defect the resting minute ventilation was related to pulmonary haemodynamics. A highly significant correlation was found between resting hyperventilation and mean 
pulmonary artery pressure, but no relation to leftto-right shunt, to total pulmonary blood flow, or to femoral artery oxygen saturation. In the mechanism of resting hyperventilation the increased ventilatory rate plays a more important role than that of the tidal volume. The possible reason for these findings has been discussed.

\section{REFERENCES}

Auchincloss, J. H., Jr., Gilbert, R., and Eich, R. H. (1959). The pulmonary diffusing capacity in congenital and rheumatic heart disease. Circulation, 19, 232.

Bing, R. J., Vandam, L. D., Handelsman, J. C., Campbell, J. A., Spencer, R., and Griswold, H. E. (1948). Physiological studies in congenital heart disease. VI. Adaptations to anoxia in congenital heart disease with cyanosis. Bull. Fohns Hopk. Hosp., 83, 439.

Campbell, J. M. H., Hunt, G. H., and Poulton, E. P. (1923). An examination of the blood gases and respiration in disease, with reference to the cause of breathlessness and cyanosis. F. Path. Bact., 26, 234.

Davies, H., and Gazetopoulos, N. (1967). Lung function in patients with left-to-right shunts. Brit. Heart f., 29, 317.

Davison, P. H., Armitage, G. H., and Arnott, W. M. (1953). The mechanisms of adaptation to a central venousarterial shunt. Brit. Heart f., 15, 221.
De Micheli, A., Villacis, E., Piccolo, E., and Espino Vela, J. (1960). Contribution à l'étude de la fonction cardiorespiratoire dans les cardiopathies congénitales. Acta cardiol. (Brux.), 15, 577.

Edwards, J. E. (1957). Functional pathology of the pulmonary vascular tree in congenital cardiac disease. Circulation, 15, 164.

Gamalero, P. C. (1957). Ricerche sulla funzionalità respiratoria nei cardiopatici congeniti. Minerva pediat., 9, 529.

Heath, D., and Whitaker, W. (1957). The small pulmonary blood vessels in atrial septal defect. Brit. Heart f., $19,327$.

Holling, H. E. (1952). Compensatory mechanisms for the anoxia of cyanotic congenital heart disease. Clin. Sci., $11,283$.

Krautwald, A., Lichterfeld, A., Kolmar, D., Hähnel, H., Garten, J., and Kiessling, J. (1962). Beziehungen zwischen Ventilation und Hämodynamik des Lungenkreislaufes bei angeborenen Herzfehlern. Klin. Wschr., 40, 125.

Ressl, J., and Kubis, M. (1968). Oxygen ventilatory equivalents at rest and during effort in adults with atrial septal defect and the relation to pulmonary haemodynamics (in Czech). Vnitrni Lék. In the press.

—, Lukl, P., Weinberg, J., and Zmeškal, A. (1961). Ventilatory function in mitral stenosis. Cor et vasa (Praha), 3, 202.

Shephard, R. J. (1955). The resting hyperventilation of congenital heart disease. Brit. Heart f., 17, 153.

Woolf, C. R. (1963). Pulmonary function in. adults with intracardiac septal defect. Circulation, 27, 261. 